\title{
IMPACT OF PHYSICAL FACTORS OF WORKPLACE ENVIRONMENT ON WORKERS PERFORMANCE IN INDUSTRY
}

\author{
Md. Al Amin* and Arka Chakraborty \\ Department of Industrial Engineering and Management, Khulna University of Engineering \&Technology, \\ Bangladesh
}

Received: 01 August 2021

Accepted: 04 November 2021

\begin{abstract}
Workers' performance and efficiency are dependent on their workplace facilities. The present study attempts to identify the six physical factors of the workplace environment: furniture and equipment design, air quality, temperature, sanitation, lighting and noise. Workers' feedback is evaluated by using 5 scale Likert method and it is found that found workplace temperature is most critical for workers' performance. The purpose of this study is to identify workers' impressions about their workplace environment and provide a better understanding to the managers about improvement. Industry-level emphasis on these factors can improve workers' performance standards and production quality. Previous work performance studies are not focused on hygiene and sanitation facility but due to the corona pandemic situation sanitation concern has been raised. This study aims to explore the relationship of these factors with gender and work experience of the workers. Variation in each group has provided an understanding of the basic demand of each type of worker.
\end{abstract}

Keywords: 5 scale Likert method, physical factors, workplace environment, and workers performance.

\section{INTRODUCTION}

Today's business world is highly competitive. Every company should maximize the utilization of its labor force rather than wasting. Workplace environment impact workers mentality, morale and most significantly their motivation towards performance (Chandrashekhar, 2011). Bangladesh has achieved remarkable improvement over the past few years in economic segment. Production sector is a major player of country's economy. This industrial sector in continuously expanding and creating employment opportunity for more and more workers. In spite of magnanimous development in industrial milieu, this sector is dealing some trouble in the case of ensuring quality work environment (Goni et al. 2020). Historically Bangladesh has witnessed major disasters like Rana Plaza incident and other destructive events in the factory which reflects the negligence of the policy makers on workplace environment improvement and security measures. From a report of ILO it is depicted that every year almost $4 \%$ of World's GDP is lost due to accidental hazard in industry (Barua \& Ansary, 2017). For a constant development in the economy sustainability is pivotal. This sustainability can be achieved by improving worker engagement situation in the workplace (Duque et al. 2020). Physical work environment includes all arrangements and compliances and stimuli that people face in their work life, this may include work space, furniture design and facility, lighting facility in the workplace, ventilation and air quality, humidity and temperature, heat passing system, sound etc. (Davis et al. 2011). Physical factors of workplace can affect the performance. They have a direct impact on concentration, safety, proactivity. In this study six physical factors are considered: workplace furniture ergonomics, adequate lighting, ventilation and air facility, workplace temperature, hygiene and sanitation. Lighting facility is highly aligned with workers visual perfection, work performance and comfort (Boyce, 2003).Direct and indirect both type of lighting system is necessary in workplace environment for keeping the balance in production (Boyce et al. 2016). With the pace of time workers visual power gradually decreases. Inadequate lighting makes this even worse. In the work environment sanitation facility is very necessary regarding safety and hygiene issue. Usually, factories in developing and under developing countries possess a poor sanitary infrastructure which leads health problem for the workers (Moran et al. 2020). The temperature in industry is usually uneven due to working condition of the process. But it is also necessary to maintain safety measures and necessary arrangements to make it suitable for the workers to perform. Being the second leading garments explorer in the world, Bangladesh needs to focus a great emphasis on that. Without proper sanitation facility many diseases like acute uncomplicated urinary tract infections (UTIs) attacked the workers specially the female workers (Knottnerus et al. 2013). After the wave of coronavirus, sanitation issue is considered severely in the industries including basic hygiene facility.

*Corresponding Author:m.alamin@iem.kuet.ac.bd https://www2.kuet.ac.bd/JES/ ISSN 2075-4914 (print); ISSN 2706-6835 (online) 
The work environment is the combination of all types of elements and surroundings that are correlated with workers and workplace productivity (Omari et al. 2017). It is a combination of both internal and external factors. A decent work environment indicates a healthy, secure, and comfortable condition which influences workers towards a positive direction (Jayaweera, 2015). It is shown that a combination between the managerial/social environment and workplace environment impacts employees' performance and productivity (Mathews et al. 2016). In this study six physical factors are considered: workplace furniture ergonomics, adequate lighting, ventilation and air facility, workplace temperature, hygiene, and sanitation.

Office furniture means table, chair, sitting facility, arrangement in the workplace. The design of furniture needs to be ergonomic to facilitate workers in their tasks. When workers are working in manual machine assembly line they have to work for a longer period or sometimes they may have sitting arrangements. Well-developed furniture can reduce workers' fatigue in the work line. Furniture design and ergonomics contribute significantly to employee Well-being and safety by enabling a comfortable workplace environment (Ahasan et al. 2003). Anthropometry, workplace principles, seat design these issues need to be focused on by the managers in the case of designing the workplace furniture (Fernandez, 1995). Furniture design is highly aligned with these comfort creations (Chim, 2018). Three types of comfort levels should be achieved in the workplace to enhance employee satisfaction and Well-being by workplace environmental model: physical comfort; psychological comfort and functional comfort.

An industry area is a place of sophisticated and delicate working where the visual performance of workers is necessary for different works: measurement, fitting, adjusting, and overall in every type of work. A poor lighting system impact workers' performance in a negative way because of lacking visual ability (Duijnhoven et al. 2019). Working under an insufficient lighting facility for a longer period can create permanent visionary damage to the workers (Vries et al. 2018). In the workplace workers need to concentrate and focus on their work and proper lighting facility is mandatory for this (Cajochen et al. 2000). Employees who work under better lighting conditions can work faster. Adequate lighting facilities, with proper contrast and clean glass, are mandatory in a workplace.

From the report of the International Labor Organization, it is mentioned that almost 80 million workers over the world annually suffer from workplace hazards and risks. One of the major reasons is they are exposed to middle and high temperatures during work (International Labor Organization, 2012) (Cai et al. 2018). High temperature may lead to direct effects on the workers like heat stroke, inflation, etc. The thermal condition has a strong relationship with the human physical and psychological condition which may be hampered due to uneven temperature conditions (Zivin et al. 2014). Suitable room temperature can improve workers' efficiency by reducing lethargy and providing a comfortable work environment.

In the workplace environment, indoor air quality is considered one of the major factors. Production areas and factories usually contain many toxic elements which pollute the air in the workplace. Consequently, indoor air is more contaminated than the outside. Indoor air pollution can cause physical problems like asthma, difficulties in breathing, skin rash, cough, vomiting, etc. (Rahman et al. 2014). For workers who spend more than 8 hours in the industry the situation is very critical for them. Air pollution occurs due to smoke, many inorganic materials, fumes used in production (Gamal et al. 2006). Air quality depends on temperature and humidity level. A ventilation facility is important to ensure the good air quality in the workplace. It helps fumes, gas, aerosols to pass out from the workplace.

Noise is an important element that can affect employees' productivity. In the workplace, many types of noises occur. Steady noise, intermittent noise, fluctuating noise, etc. (Lee et al. 2019). Use of heavy machines: air compressor, roller, hammer, breaker, blower, drilling machine, pump, excavator, etc. are infamous for noise creation in the industry. Adverse effects of noises can be described as auditory problems, nuance, disturbance, speech interference. These directly impact workers' productivity. In the workplace, both acoustic and non-acoustic noise can create adverse effects on the workers. Continuous noise creates mental issues in the human body. For this reason, individual faces concentration problem in their regular activities. Workers usually have to highly focus on their tasks. Bust excessive noise creates obstacles in their orientation to work and causes physical problems.

Factory and workstations are such places where workers stay for at least 8 hours a day. During this long stay human body needs to perform urination and other human activities. Sanitation facility includes hygiene, cleanliness, and sewerage facility in the workplace. This indicated the importance of sanitation facilities in the workplace. Proper infrastructure and maintenance in the sanitation system are needed. If there is not adequate washroom and toilet facilities workers cannot have proper comfort when they have to use that. Lack of sanitation facilities can create urinary tract infections and other diseases which reduces workers' performance by affecting 
their health. During this covid situation, it has become mandatory for the companies to ensure proper sanitation facilities by providing enough washing facility and cleanliness in the workplace. The sanitation facility was generally neglected both by the factory authority and also by the workers. But now this phenomenon is being highly practiced in the industries to ensure safety in the workplace.

The aim of this study is to identify the importance of these physical factors in industry and make it visible to managerial perspective about the importance and priority of the factors. This main objective of this study is to identify the importance of physical factors in workplace environment and to provide a better understanding about workers demand in workplace environment in order to enhance their work efficiency.

\section{RESEARCH METHODOLOGY}

This section represents an adoption of five scale Likert method to analyze the influence of impact factor (Figure 1). The survey responses are analyzed and the factors are ranked according to their impact. The responses are also analyzed according to the gender of workers and the work experience of workers to get a detailed observation.

\begin{tabular}{|c|c|c|c|c|c|c|}
\hline $\begin{array}{ll} & \text { Step 1: } \\
\text { Sampling } \\
\text { - } \quad \text { Selection of } \\
430 \text { industrial } \\
\text { workers from } \\
\text { numerous } \\
\text { industry } \\
\text { - Selection of } \\
\text { manager and } \\
\text { senior manager } \\
\text { for overview } \\
\text { and responses }\end{array}$ & $\Rightarrow$ & $\begin{array}{l}\text { Step 2: } \\
\text { Surveying } \\
\text { Contact the } \\
\text { selected } \\
\text { responders by } \\
\text { face to face } \\
\text { interaction and } \\
\text { record the } \\
\text { responses } \\
\text { Interpret the } \\
\text { responses in } \\
\text { Likert scale } \\
\text { format. }\end{array}$ & 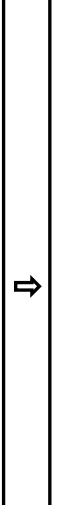 & $\begin{array}{l}\text { Step 3: } \\
\text { Analyzing Responses } \\
\text { - } \quad \text { Use of Microsoft } \\
\text { Excel } 2016 \text { to } \\
\text { categorize the } \\
\text { responses } \\
\text { - } \quad \text { Identify the } \\
\text { calculated score } \\
\text { of each factor }\end{array}$ & $\Rightarrow$ & $\begin{array}{l}\text { Step 4: } \\
\text { Analysis of Physical } \\
\text { Factors Based on } \\
\text { Workers } \\
\text { Performance } \\
\text { - Rank of the } \\
\text { factors } \\
\text { - Gender-based } \\
\quad \text { analysis of the } \\
\text { factors } \\
\text { - Work Experience } \\
\text {-based analysis } \\
\text { of the factors. }\end{array}$ \\
\hline
\end{tabular}

Figure 1: Research Protocol

The methodological approach used to analyze the study is the Likert scale by questionnaire, which was administered to a sample of 430 users. The Likert scale has been repeatedly used in many application areas. The Likert scale is a psychometric scale that is used to transfer the qualities into a quantitative measure of analysis and express the quantitative measure of attitude, character and personality traits. Questions designed using the Likert scale must either be in agreement or disagreement. In a Likert scale survey, the survey participants are asked to express their levels of agreement and disagreement with a series of options. Each of the agreement and disagreement degrees is assigned a numeric value on a scale. The Likert are usually 5 or 7 point scale. In this study, the 5 scales Likert method is used. The Likert scale has some drawbacks due to the biasness of survey responders with the corresponding statements (Pimentel, 2010). Following questions are asked to the survey participants.

We included 430 workers among them 260 are male which is $60 \%$ of the total survey population. There are 170 female participants which was $40 \%$ of the total survey population (Table 2).

180 workers are with less than 5 years of work experience in our survey which is $42 \%$ of the total survey population. 130 workers are mid seniority level working experience with somehow between 6-10 years' service experience. And 120 workers are having 11 years and more of service experience are involved in this study. They are $28 \%$ of our survey population. According to the demographic of the responders, the opinion varies. We have considered 6 physical factors of the workplace environment and identified their relation. This research is performed with the direct interaction with the responders in 5 scales Likert process. Workers from different industries are involved in the study and their responses are recorded. Responses had been recorded in 5 scales. Strongly Agree, Agree, Neutral, Disagree, Strongly Disagree (Table 1). 
Table 1: Survey Questionnaire

\begin{tabular}{lccccc}
\hline Survey Questions & Strongly agree & Agree & Neutral & Disagree & $\begin{array}{c}\text { Strongly } \\
\text { Disagree }\end{array}$ \\
\hline $\begin{array}{l}\text { Furniture and equipment } \\
\text { facility is mandatory in the } \\
\text { workplace }\end{array}$ & 5 & 4 & 3 & 2 & 1 \\
$\begin{array}{l}\text { Ventilation facility is the } \\
\text { mandatory in workplace }\end{array}$ & 5 & 4 & 3 & 2 & 1 \\
$\begin{array}{l}\text { Temperature control is } \\
\text { mandatory in the workplace }\end{array}$ & 5 & 4 & 3 & 2 & 1 \\
$\begin{array}{l}\text { Lighting facility is vital in the } \\
\text { workplace }\end{array}$ & 5 & 4 & 3 & 2 & 1 \\
$\begin{array}{l}\text { Air quality maintenance is } \\
\text { important in the workplace }\end{array}$ & 5 & 4 & 2 & 2 & 1 \\
$\begin{array}{l}\text { Hygiene \& Sanitation facility } \\
\text { is mandatory in the workplace }\end{array}$ & 5 & 4 & 2 & 2 & 1 \\
\hline
\end{tabular}

Table 2: Gender-based categorization:

\begin{tabular}{lcc}
\hline Total Population of the survey & Male & Female \\
\hline 430 & 260 & 170 \\
\hline
\end{tabular}

Table 3: Categorization on the basis of work experience:

\begin{tabular}{lll}
\hline Years of Service & Number of Workers & Percentage \\
\hline $0-5$ years & 180 & $42 \%$ \\
$6-10$ years & 130 & $30 \%$ \\
$11+$ years & 120 & $28 \%$ \\
\hline
\end{tabular}

Responses from the workers are collected for each factor. Responses are categorized in the previously mentioned criteria. This was represented in percentage value for better understanding (Table 3). Then the value of the each criterion was multiplied with their weighted score.

Total Score $=\Sigma\left(\right.$ percentage of response in criteria* ${ }^{*}$ weighted value of designated criteria $)$

Example: Impact score of furniture and equipment design

$=(26 \% * 5+35 \% * 4+28 \% * 3+12 \% * 2+0 \% * 1)$

$=3.78$

Weight of each scale in the traditional Likert scale method (Table 4) is used in relevant research studies (Pimentel, 2010) 
Table 4: Weight score value of Likert scale

\begin{tabular}{lcc}
\hline Decision & Weight Range & Traditional Weight Value \\
\hline Strongly Agree & $1-1.79$ & 1 \\
Agree & $1.80-2.59$ & 2 \\
Neutral & $2.60-3.39$ & 3 \\
Disagree & $3.40-4.19$ & 4 \\
Strongly Disagree & $4.20-5$ & 5 \\
\hline
\end{tabular}

\section{ANALYSIS AND INTERPRETATION}

In order to have that understanding and to identify that subtle difference we are discussing the factors individually.

\subsection{Factor 1: Furniture and Equipment Designs}

Previously we have seen $26 \%$ of the entire response strongly agree about the impact of furniture and equipment design and their ergonomics. Here we can see $41 \%$ female population strongly agreed which is quite higher than male $15 \%$. But the male population also agreed $46 \%$ which is higher than $18 \%$ of the female population (Table 5). Both male and female workers considered it important but female workers felt its urgency more strongly than the male workers. We have observed workers with the increase of service experience were feeling the necessity more about furniture and equipment and ergonomics. The workers with 11+ years' experience have the highest number of opinions on the "strongly agree" pole. On the contrary percentage of "disagree" is also higher in this category. Response from the workers with 6-10 years of work experience is quite similar with the total average response. Workers with less than 5 years' service experience strongly agreed in $17 \%$ of cases and $50 \%$ of them agreed about the impact of this factor.

\subsection{Factor 2: Ventilation \& Air Quality:}

Male workers responded $27 \%$ as strongly agree with the impact of ventilation facility and quality airflow in the workplace. Whereas $12 \%$ of female workers strongly agreed with that. $8 \%$ of total male workers disagreed with this statement. There was no disagree from the female workers.

$28 \%$ of workers from less than 5 years' experience category strongly agreed with the impact of this factor. $25 \%$ of workers from $11+$ years' work experience category strongly agreed with this decision. This percentage is significantly lower in the case of workers with 6-10 years' experience. Only 8\% of them strongly agreed but the majority of the $77 \%$ agreed about the impact of this factor. But none of them disagreed about the impact of this factor.

\subsection{Factor 3: Temperature}

$50 \%$ of male workers strongly agreed and $23 \%$ agreed about the impact of workplace temperature on their work performance while $29 \%$ of female workers strongly agreed and $53 \%$ with that. $6 \%$ of female workers disagreed about the impact of this factor. $27 \%$ male workers and $12 \%$ female workers were neutral about the impact of this factor. $67 \%$ of workers from $11+$ years' work experience strongly agreed which is more than double of $33 \%$ from less than 5 years experienced group and $31 \%$ of $6-10$ years experienced group. But $8 \%$ of $11+$ years experienced group disagreed about the impact of this factor, where there is no disagreement from the two others category. A significant portion of $38 \%$ of workers from the 6-10 years experienced group was neutral about this factor's impact.

Table 5: Gender based impact analysis of physical factors of workplace environment on workers performance

\begin{tabular}{llllllll}
\hline $\begin{array}{l}\text { Gender } \\
\text { Workers }\end{array}$ & & Factor 1: & Factor 2: & Factor 3: & Factor 4: & Factor 5: & Factor 6: \\
\hline Male & $\begin{array}{l}\text { Strongly } \\
\text { agree }\end{array}$ & $15 \%$ & $27 \%$ & $50 \%$ & $15 \%$ & $15 \%$ & $19 \%$ \\
\cline { 2 - 6 } & & & & & & & \\
\hline
\end{tabular}




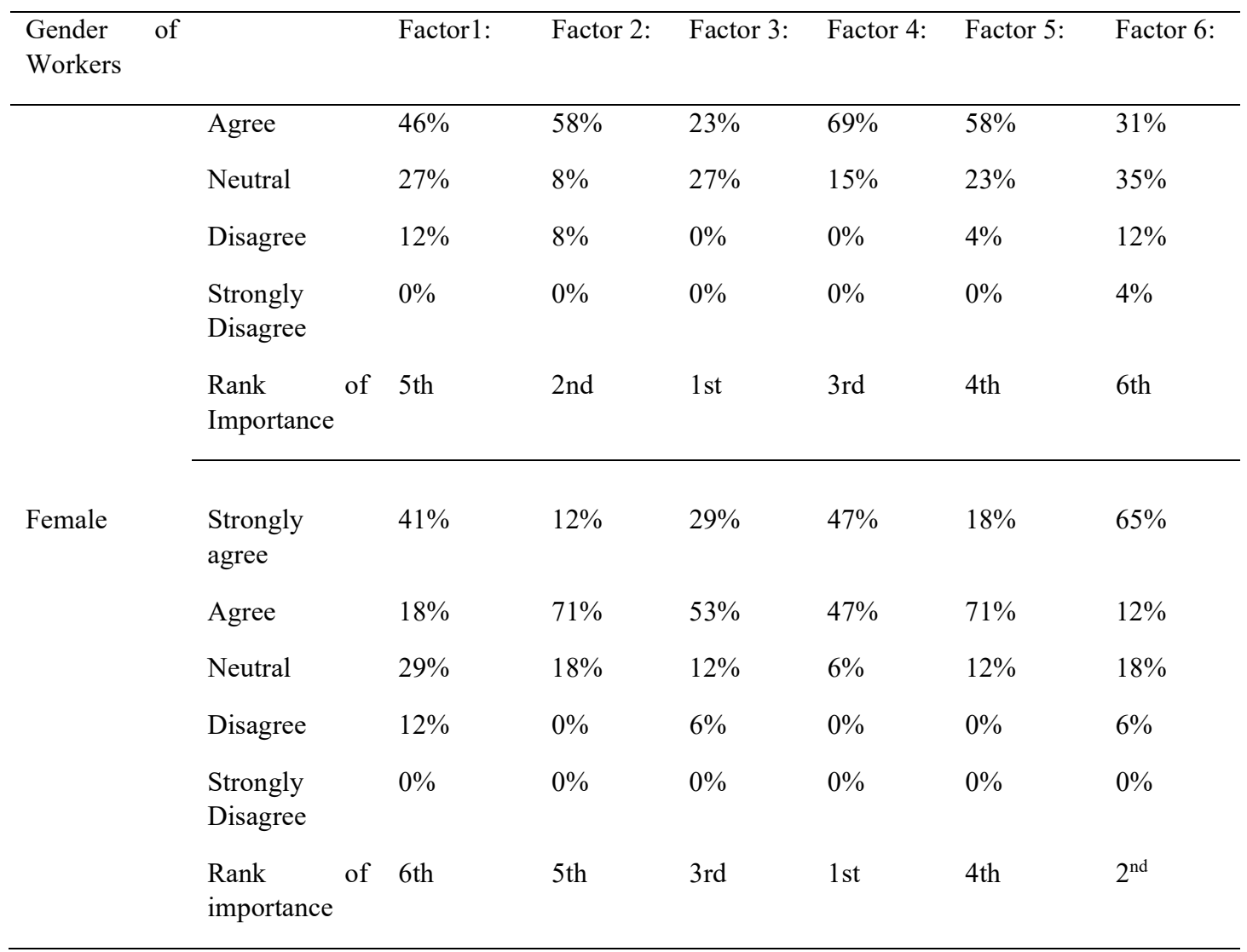

\subsection{Factor 4: Lighting Facility in the Workplace}

From the female responders, $47 \%$ strongly agreed about the impact of lighting facilities in their workforce which is higher than $15 \%$ from the male workers. $42 \%$ of workers with more than $11+$ years' responsibility strongly agreed about the impact of lighting factor this is almost double comparing to $22 \%$ from $0-5$ years experienced workers group and 6-10 years experienced workers group. Al of the workers of the 11+ years experienced category responded in the strongly agree and agree category and there is no other category response from this group of people which is significant.

$15 \%$ of male workers strongly agreed and $18 \%$ of female workers strongly agreed about the impact of noise on their work performance. No female workers disagreed here but $4 \%$ of male responders disagreed about noise's impact on their work performance. In this factor, we can see a great portion of the response was neutral and this is more than strongly agreed response overall. Workers from $0-5$ years experienced category $22 \%$ strongly agreed and $72 \%$ agreed about its impact. This is higher than two other categories of workers. $31 \%$ of workers from the 6-10 years' experience category are neutral about the impact and $8 \%$ of workers from this category disagreed with the impact of this factor. This is the only group that disagreed about the impact of noise on work performance.

\subsection{Factor 6: Sanitation Facility in the Workplace:}

$65 \%$ of female workers strongly agreed that sanitation facility in the workplace has a major impact which is almost 3.5 times higher than male responders where $19 \%$ of them strongly agreed with that. On the contrary, $6 \%$ of female workers disagreed with that and $12 \%$ of male workers responders disagreed with it. It is the only factor where we observed strongly disagree responses and all of them from male workers. With the increase of recent covid situation, concern in this sector is uprising. But there are also some backlashes in a particular class due to a lack of proper awareness activities.

The variation in response is comparatively lower in all the categories except the strongly disagree category. This is the only factor where we have noticed strongly disagree responses and all of them are from workers with 11+ years of working experience. 
Table 6: Work experienced based impact analysis of physical factors of workplace environment on workers performance

\begin{tabular}{|c|c|c|c|c|c|c|c|}
\hline $\begin{array}{l}\text { Working } \\
\text { Experience }\end{array}$ & & Factor1: & Factor 2: & Factor 3: & Factor 4: & Factor 5: & Factor 6 \\
\hline \multirow[t]{6}{*}{$0-5$ years } & $\begin{array}{l}\text { Strongly } \\
\text { agree }\end{array}$ & $17 \%$ & $28 \%$ & $33 \%$ & $22 \%$ & $22 \%$ & $39 \%$ \\
\hline & Agree & $50 \%$ & $56 \%$ & $50 \%$ & $56 \%$ & $72 \%$ & $22 \%$ \\
\hline & Neutral & $22 \%$ & $11 \%$ & $17 \%$ & $22 \%$ & $6 \%$ & $28 \%$ \\
\hline & Disagree & $11 \%$ & $6 \%$ & $0 \%$ & $0 \%$ & $0 \%$ & $11 \%$ \\
\hline & $\begin{array}{l}\text { Strongly } \\
\text { Disagree }\end{array}$ & $0 \%$ & $0 \%$ & $0 \%$ & $0 \%$ & $0 \%$ & $0 \%$ \\
\hline & $\begin{array}{l}\text { Rank of } \\
\text { Importance }\end{array}$ & 6th & $3 \mathrm{rd}$ & $1 \mathrm{st}$ & 4 th & 2nd & 5 th \\
\hline \multirow[t]{6}{*}{$6-10$ years } & $\begin{array}{l}\text { Strongly } \\
\text { agree }\end{array}$ & $23 \%$ & $8 \%$ & $31 \%$ & $23 \%$ & $8 \%$ & $38 \%$ \\
\hline & Agree & $38 \%$ & $77 \%$ & $31 \%$ & $69 \%$ & $54 \%$ & $31 \%$ \\
\hline & Neutral & $31 \%$ & $15 \%$ & $38 \%$ & $8 \%$ & $31 \%$ & $23 \%$ \\
\hline & Disagree & $8 \%$ & $0 \%$ & $0 \%$ & $0 \%$ & $8 \%$ & $8 \%$ \\
\hline & $\begin{array}{l}\text { Strongly } \\
\text { Disagree }\end{array}$ & $0 \%$ & $0 \%$ & $0 \%$ & $0 \%$ & $0 \%$ & $0 \%$ \\
\hline & $\begin{array}{l}\text { Rank of } \\
\text { importance }\end{array}$ & 5 th & 4 th & $3 \mathrm{rd}$ & $1 \mathrm{st}$ & 6th & 2nd \\
\hline \multirow[t]{6}{*}{$10+$ years } & $\begin{array}{l}\text { Strongly } \\
\text { agree }\end{array}$ & $42 \%$ & $25 \%$ & $67 \%$ & $42 \%$ & $17 \%$ & $33 \%$ \\
\hline & Agree & $8 \%$ & $58 \%$ & $17 \%$ & $58 \%$ & $58 \%$ & $17 \%$ \\
\hline & Neutral & $33 \%$ & $8 \%$ & $8 \%$ & $0 \%$ & $25 \%$ & $33 \%$ \\
\hline & Disagree & $17 \%$ & $8 \%$ & $8 \%$ & $0 \%$ & $0 \%$ & $8 \%$ \\
\hline & $\begin{array}{l}\text { Strongly } \\
\text { Disagree }\end{array}$ & $0 \%$ & $0 \%$ & $0 \%$ & $0 \%$ & $0 \%$ & $8 \%$ \\
\hline & $\begin{array}{l}\text { Rank of } \\
\text { importance }\end{array}$ & 5 th & $3 \mathrm{rd}$ & 2nd & $1 \mathrm{st}$ & 4 th & 6th \\
\hline
\end{tabular}

\section{RESULTS \& DISCUSSION}

From the 6 factors overall ranking, the temperature was considered as the most important factor, lighting facility as the second most important factor. Ventilation and air quality, noise, sanitation facility, and furniture and equipment design were ranked in the following order based on importance from the workers' perspective. Workers considered temperature as the most important factor which impacts their performance. $42 \%$ of the total workers consider this highly important. Industries where the workers have to work in high temperature i.e.: iron 
manufacturing, cement manufacturing workers suffered greatly due to this factor. Workers expressed their concern about sanitation facilities in the workplace. This study has been performed in the year of this covid situation. That is the reason why many workers considered the impact of proper sanitation facilities. Companies also promote the impact of sanitation and redesigned the sanitation facility in recent times. $37 \%$ of entire workers considered this as a major determinant of their work performance. But this is the only factor where the study observes a strongly disagree response from the workers, which is $2 \%$. This $2 \%$ expressed that sanitation facility is not mandatory compared with other factors. $28 \%$ population strongly agreed that lighting has an important impact on their work. It is the only factor where no workers disagreed about its impact. The response about furniture and equipment facilities is pretty diversified. $26 \%$ of workers strongly agreed about its impact. $35 \%$ of workers agreed and $28 \%$ were neutral about this factor's impact (Table 7). Among all the factors this was the highest rate where survey responders were in a neutral position about the impact. And 12\% of workers disagreed about its impact. Ventilation and air quality are moderately considered important among the workers

Table 7: Effects of physical factors of workplace environment on workers performance

\begin{tabular}{llllllll} 
& $\begin{array}{l}\text { Strongly } \\
\text { agree }\end{array}$ & Agree & Neutral & Disagree & $\begin{array}{l}\text { Strongly } \\
\text { Disagree }\end{array}$ & $\begin{array}{c}\text { Total } \\
\text { Score }\end{array}$ & Rank \\
\hline $\begin{array}{l}\text { Factor 1: Furniture and } \\
\text { equipment designs }\end{array}$ & $26 \%$ & $35 \%$ & $28 \%$ & $12 \%$ & $0 \%$ & 3.78 & $6^{\text {th }}$ \\
$\begin{array}{l}\text { Factor 2: Ventilation } \\
\text { Factor 3: Temperature }\end{array}$ & $21 \%$ & $63 \%$ & $12 \%$ & $5 \%$ & $0 \%$ & 4.03 & $3^{\text {rd }}$ \\
Factor 4: Lighting & $28 \%$ & $60 \%$ & $12 \%$ & $0 \%$ & $0 \%$ & 4.16 & $2^{\text {nd }}$ \\
Factor 5: Noise & $16 \%$ & $63 \%$ & $19 \%$ & $2 \%$ & $0 \%$ & 3.93 & $4^{\text {th }}$ \\
Factor 6: Sanitation & $37 \%$ & $23 \%$ & $28 \%$ & $9 \%$ & $2 \%$ & 3.81 & $5^{\text {th }}$ \\
\hline
\end{tabular}

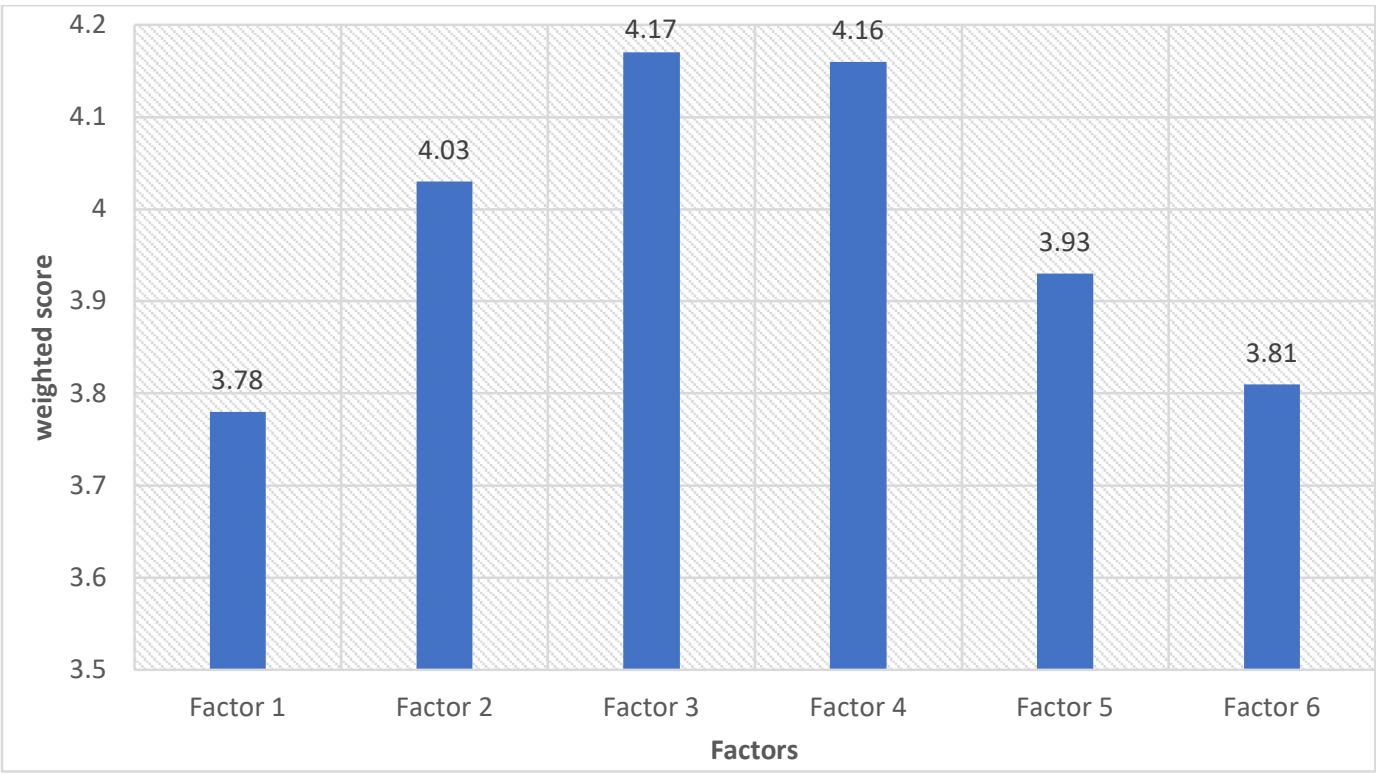

Figure 2: Weighted score of the physical factors

$21 \%$ of workers strongly agreed and $63 \%$ of workers agreed that this factor is important in their work environment. $16 \%$ of workers strongly agreed about the impact of noise and sound quality. It is the lowest rate where responders were strongly agreed about a factor. However, $63 \%$ of workers agreed about its impact on their work-life. 


\section{CONCLUSIONS}

This research fulfilled its' objective by showing the impact of 6 physical factors of the workplace environment on their performance. In this process, this research also focuses on the impact of the factors according to the gender of the workers and their work experience. In the industrial sector understanding the workers' psychology regarding their workplace will be understandable for the managers with the finding of this study. Likert scale analysis is used for understanding this psychological impression and expressing the qualitative value in quantitative measures. Managers should make their plan and worker management policy keeping focus on these factors. This research also exhibited the priority of the workers' demand among these factors. This may help the managers to prioritize and make cost-effective decisions to execute workplace environment maintenance policy.

The research is based on the verbal responses from the workers which is expressed on Likert scale. In this process, a proper quantitative model can't be developed. For that reason, the outcome of this study may vary from industry to industry and based on the demographic of the worker. However, to reduce this, gender-based response analysis and work experience-based analysis are also performed. In the future, the combined correlation between gender and work experience in the workplace environment can be described and a mathematical model can be developed. This study shows the importance of ranking. There is the future scope for analyzing the reasons behind the deviation in the ranking of the factors. These can help to make the betterment of the workplace for the workers which will increase the overall performance and productivity.

\section{REFERENCES}

A.A, O., Gamal, K, M. E., \& A.A., A. (2006). Correlation between indoor environmental quality and productivity in buildings. In M. K. Tolba, A. Abdel-Hadi, \& S. Soliman (Ed.), Environment, health and sustainable development, Proceedings of the 19th of IAPS, Cairo. Cairo.

Ahasan, R., \& Imbeau, D. (2003). Who belongs To Ergonomics? Work Study, 52(3), 123- 128.

Al-Omari, K., \& Okasheh., H. (2017). The Influence of Work Environment on Job Performance: A Case Study of Engineering Company in Jordan. International Journal of Applied Engineering Research, 12(24), 15544-15550.

Al-Omari, K., \& Okasheh., H. (2017). The Influence of Work Environment on Job Performance: A Case Study of Engineering Company in Jordan. International Journal of Applied Engineering Research, 12(24), 15544-15550.

Bart J. Knottnerus, M. P., Suzanne E. Geerlings, M. P., Eric P. Moll van Charante, M. P., \& Gerben ter Riet, M. P. (2013). Toward A Simple Diagnostic Index for Acute Uncomplicated Urinary Tract Infections. The Annals of Family Medicine, 11(5), 442-451. doi: 10.1370/afm.1513

Barua, U., \& Ansary, M. A. (2017). Workplace safety in Bangladesh ready-made garment sector: 3 years after the Rana Plaza. International Journal of Occupational Safety and Ergonomics (JOSE), 23(4), 578-583.

Boyce, P. R. (2003). Human factors in lighting (2nd ed.). London, England: Taylor \& Francis.

Cai, X., Lu, Y., \& Wang., J. (2018). The impact of temperature on manufacturing worker productivity:Evidence from personnel data. Journal of Comparative Economics, 46(4), 889-905. doi:10.1016/j.jce.2018.06.003

Cajochen, C., Zeitzer, J. M., Czeisler, C. A., \& Dijk., D.-J. (2000). Dose-response relationship for light intensity and ocular and electroencephalographic correlates of human alertness. Behavioural Brain Research, 115(1), 75-83. doi:10.1016/s0166-4328(00)00236-9

Chandrasekar, D. K. (2011). Workplace Environment And Its Impact On Organisational Performance In Public Sector. International Journal of Enterprise Computing and Business Systems, 1(1), 1-19.

Chim, J. M. (2018). 6Ws in Ergonomics Workplace Design. In S. T. Bagnara (Ed.), Congress of the International Ergonomics Association (pp. 1282-1286). Springer, Cham. doi:https://doi.org/10.1007/978-3-31996071-5_129

Davis, M. C. (2011). The Physical Environment of the Office:Contemporary and Emerging Issues. In $G$. P.Hodgkinson \& J. K. Ford (Eds.), International Review of Industrial and Organizational Psychology, 26, 193 - 235.

Duijnhoven, V., Aarts, M., \& Kort., H. (2019). The Importance of Including Position and Viewing Direction When Measuring and Assessing the Lighting Conditions of Office Workers. Work, 64(4), 877 - 895. doi:10.3233/WOR-193028

Duque, L., Costa, R., Dias, Á., Pereira, L., Santos, J., \& António, N. (2020). New Ways of Working and the Physical Environment. Sustainability, 12(17), 6759. . doi:10.3390/su12176759

Fernandez, J. E. (1995). Ergonomics in the workplace. Facilities, 13(4), 20-27. Retrieved from https://doi.org/10.1108/02632779510083359 
Hu, X., Yan, H., Casey, T., \& Wu., C.-H. (2020). Creating a safe haven during the crisis: How organizations can achieve deep. International Journal of Hospitality Management, 92. Retrieved from https://doi.org/10.1016/j.ijhm.2020.102662

International Labor Organization. (2012). Sectoral activities department (SECTOR). Retrieved from www.ilo.org: https://www.ilo.org/sector/lang--en/index.htm

Jacxelyn Moran, T. J.-C. (2020). Urinary symptoms and infections among female garment factory workers in Bangladesh. Work, 65(4), 847-856. doi:10.3233/WOR-203136

Jayaweera, T. (2015). Impact of Work Environmental Factors on Job Performance,Mediating Role of Work Motivation: A Study of Hotel Sector in England. International Journal of Business and Management, 10(3).

Lee, S. C., Kim, J. H., \& Hong, J. Y. (2019). Characterizing perceived aspects of adverse impact of noise on construction managerson construction sites. Building and Environment, 152, 17-27. doi:doi.org/10.1016/j.buildenv.2019.02.005

Mathews, C., \& Khann, I. K. (2016). Impact of Work Environment on Performance of Employees in Manufacturing Sector in India:Literature Review. International Journal of Science and Research (IJSR), 5(4), 852-855.

Md. Abdul Goni, P., Rahman, K. M., \& Md. Mostafizur Rahman, P. (2020). Factors Affecting Employee's Satisfaction about Workplace Environment: A. Middle East Journal of Applied Science \& Technology (MEJAST), 3(3), 58-67.

Ph.D., P. B., Ph.D., J. V., Newsham, G., Jones, C., Ph.D, J. H., Myer, M., \& Hunter, C. (2006). Lighting quality and office work: Two field simulation experiments. Lighting Research \&Technology, 38(3), 191-223.

Pimentel, J. L. (2010). A note on the usage of Likert Scaling for research data analysis. USM R\&D Journal, 109112.

Rahman, M., Musa, M., \& Jeni., M. (2014). The Review on Significant Adverse Impact of Poor Indoor Air Quality on. Advanced Materials Research, 931-932, 749-753. doi:10.4028

Sarode, D. A., \& Shirsath, M. (2014). The Factors Affecting Employee Work Environment \& It's Relation with Employee Productivity. International Journal of Science and Research (IJSR), 3(11).

Sarode, D. A., \& Shirsath, M. (2014). The Factors Affecting Employee Work Environment \& It's Relation with Employee Productivity. International Journal of Science and Research (IJSR) ISSN (Online): 2319-7064 Impact Factor (2012): 3.358, 3(11).

Vries, A., Souman, J. L., Ruyter, B. d., Heynderick, I., \& Y. A. (2018). Lighting up the office: The effect of wall luminance on room appraisal, office workers. Building and Environment, 142, 534-543. doi:10.1016/j.buildenv.2018.06.046

Zivin, J. G., \& Neidell, M. (2014). Temperature and the Allocation of Time: Implications for Climate Change. Journal of Labor Economics, 32(1), 1-26. doi:10.1086/671766

(C) 2021 the JES. Journal of Engineering Science published by Faculty of Civil Engineering, Khulna University of Engineering \& Technology. This is an open access article under the terms of the Creative Commons Attribution-NonCommercialNoDerivatives License, which permits use and distribution in any medium, provided the original work is properly cited, the use is non-commercial and no Modifications or adaptations are made. 